\title{
Influence of Probiotic Preparations on Meat Quality of Farm Animals
}

\author{
Kurchaeva Elena \\ Faculty of Veterenary Medicine \\ and Animal Husbandry Technology \\ Voronezh State Agrarian Univercity named after \\ Emperor Peter the Great \\ Voronezh, Russia \\ alena.kurchaeva@yandex.ru \\ Vostroilov Aleksander \\ Faculty of Veterinary Medicine \\ and Animal Husbandry Technology \\ Voronezh State Agrarian Univercity named after \\ Emperor Peter the Great \\ Voronezh, Russia \\ kaftchz@,veterin.vsau.ru
}

\author{
Ovsynnikova Galina \\ Faculty of Technology and Merchandizing \\ Voronezh State Agrarian Univercity named after \\ Emperor Peter the Great \\ Voronezh, Russia \\ frauovs@yandex.ru \\ Maksimov Igor \\ Faculty of Technology and Merchandizing \\ Voronezh State Agrarian Univercity named after \\ Emperor Peter the Great \\ Voronezh, Russia \\ maximus880@mail.rud
}

\begin{abstract}
The use of probiotic additives that contribute to the normalization of microbiocenosis of the animal body, as well as their resistance to pathogenic microflora, which ultimately affects the increase in meat productivity is promising for the livestock industry. The aim of the research was to study the effect of probiotic preparation "Subtilis-C" on the productivity and quality, on the meat quality of pigs and rabbits in industrial technology.
\end{abstract}

Two groups of hybrid young animals (large white $x$ Landras $x$ pietren (terminal line MAXGRO ${ }^{\mathrm{TM}}$ ) of pigs of 35-day age of 15 heads were formed for carrying out scientific and economic experiment by the method of pairs-analogues. In the main period of the experiment, the animals of the control group received the main ration (MR), consisting of complete all-mash: SC 4-7; experimental - (MR) plus the preparation "Subtilis C" as part of the feed at a dosage of $0.4 \mathrm{~g} / \mathrm{kg}$ of feed. The studies were conducted on the basis of the industrial complex to produce pork in the Liskinsky district of the Voronezh region. During the study animals were clinically healthy and were in the same conditions.

To evaluate the effect of the probiotic preparation "Subtilis" when fattening young rabbits 30 rabbits (males) of hybrid breeds, New Zealand red and Soviet chinchilla were selected at the age of 60 days, and on the principle of groups of analogues they were divided into 3 groups of with 10 heads in each. Studies were conducted concerning the number of young rabbits in the private sector of the Voronezh region in 2018. Rabbits of group 1 (control) received only all-mash PK-90, rabbits of groups 2 and 3 were given, in addition to the main diet, the probiotic preparation "Subtilis C" composed of all-mash in a dosage of $3 \mathrm{~g} / \mathrm{kg}$ (rabbits of experimental group 1) and $4 \mathrm{~g} / \mathrm{kg}$ of feed (rabbits of experimental group 2).

It was found that during the main period of scientific and economic experience the absolute increase in live weight of young pigs of the control group amounted to $79.70 \mathrm{~kg}$, those of experimental $-82.60 \mathrm{~kg}$, which is more than the animals of the control group, respectively, by $2.70 \mathrm{~kg}$. The results of the control slaughter showed that the slaughter live weight of pigs of the experimental group in comparison with the animals of the control group was higher, respectively, by $3.56 \mathrm{~kg}$.

Upon reaching the slaughter age (120 days) rabbits of the $1 \mathrm{st}$ group (control) were characterized by live weight, which was less than the mass of individuals of the 2 nd group (1st experimental group) by $138.0 \mathrm{~g}$, or $4.31 \%(\mathrm{P}<0.05)$, the 3 rd group $\left(2^{\text {nd }}\right.$ experimental group) - by $324.7 \mathrm{~g}$, or $10.15 \%(\mathrm{P}<0.01)$. The highest pre-slaughter weight of young rabbits was $(3245 \mathrm{~g})$ in experimental group 2 and in comparison with the control one it was higher by $165.7 \mathrm{~g}$, or $5.38 \%(\mathrm{p}<0.05)$. The carcass yield in the $2^{\text {nd }}$ experimental group was $62.33 \%$, which is more than in the control group and $1^{\text {st }}$ experimental group by 6.86 and $2.12 \%$, respectively.

The level of profitability of pork production was higher in the experimental group compared to the control group by $3.6 \%$, rabbit production - by $\mathbf{1 . 8 \%}$ (in the 1 st experimental group) and $2.6 \%$ (in the 2nd experimental group) higher compared to the control group of rabbits. Thus, the preparation "Subtili-C" is a promising product of a number of probiotics used in animal feeding and allows obtaining environmentally friendly products of pig and rabbit breeding with improved economic performance.

Keywords-probiotic preparation, number of young rabbits, hybrid young pigs, meat productivity.

\section{INTRODUCTION}

In recent years, the Russian meat market has entered a phase of stable development; the country has ceased to be the largest importer of raw meat; the industry faces the task of increasing export potential [1]. Natural and economic resources of the Voronezh region and prioritization of livestock development contributed to the fact that in terms of food security, the region is profitable, while the region covers its own meat needs by $300 \%$. Niches of ethnic organic products, including lamb, rabbit 
meat $[2,12,14-20,24-26,29]$, are growing and fixed in the market.

In modern conditions, serious attention is paid to food safety. In order to maintain its position in the domestic highly competitive market and for Russian producers to enter the external market, it is necessary to introduce a system of food safety that meets international standards - HACCP (Hazard Analysis and Critical Control Points) [3] the basis of which is a systematic approach, covering the parameters of food safety from obtaining the raw materials to the use of the finished product by the consumer [32-34].

One of the main biological risks in pig and rabbit breeding enterprises is the high sensitivity of livestock to pathogenic microflora. This factor is largely due to the high concentration of livestock per unit of area. Therefore, minimizing the reproduction of microflora in the animal's body is the main task of growing and fattening young animals in intensive technologies. For this purposed, antibiotics are used as feed additives, the mechanism of action of which is that they can reduce the competition of microorganisms in the fight for nutrients with the body and reduce their metabolites that inhibit the growth of the animal [4]. In the context of the struggle for food safety, the use of antibiotics in animal husbandry is unacceptable.

At present, probiotic forage preparations have been widely used as a potential replacement for antibiotics not only to maintain the microbial balance of the gastrointestinal tract, but also to increase the productivity of animals $[5,6,7,8,12,13$, $23,31]$.

It is proved that the positive results show probiotics, which are based on spore-forming bacteria of the genus Bacillus. On the basis of strains of bacteria B. Subtilis (strain VKM V-2250, patent RF № 2184774) and B. Licheniformis (strain VKM In 2252, patent RF № 2203947) Institute of probiotics, a number of products with a wide spectrum of action is intended for use in intensive livestock production [9-11, 23]. Strains of bacteria of the prepaption "Subtili-C" have a pronounced antagonistic activity against Clostridium perfringens, Escherichia coli, Salmonella typhimurium, Salmonella enteritidis, Staphilococcus aureus, Shigella sp. and others;

The aim of the research is to study the effect of probiotic preparation "Subtilis-C" on the productivity and meat quality of pigs and rabbits in industrial technology.

\section{MATERIAL AND METHODS OF RESEARCH}

Two groups of hybrid young animals (large white $\mathrm{x}$ Landras $x$ pietren (terminal line MAXGRO ${ }^{\mathrm{TM}}$ ) of pigs in 35-day age of 15 heads were formed for carrying out scientific and economic experience by the method of pairs-analogues. In the main period of the experiment, the animals of the control group received the main ration (MR), consisting of complete all-mash: SC 4-7; experimental - (MR) plus the preparation "Subtilis C" as part of the all-mash at a dosage of $0.4 \mathrm{~g} / \mathrm{kg}$ of feed. The studies were conducted on the basis of the industrial complex for the production of pork in the Liskinsky district of the Voronezh region. During the study animals were clinically healthy and were in the same conditions.
To evaluate the effect of the probiotic preparation "Subtilis $-\mathrm{C}$ " in fattening young rabbits, we selected 30 rabbits (males) of hybrid breeds new Zealand red and Soviet chinchilla at the age of 60 days, which on the principle of groups of analogues were divided into 3 groups. Rabbits of all groups were kept in the same conditions and received the same basic diet. As the main ration we used all-mash PK-90-1, obtained on the basis of cereals, sunflower cake and amaranth, wheat bran, Jerusalem artichoke powder, herbal flour from alfalfa and green mass of Jerusalem artichoke and premix KVP P90-1K. Feed rations were calculated on the basis of physiological needs and existing norms of feeding rabbits. Rabbits of group 1 (control) received only all-mash PK-90-1 (main ration), rabbits of groups 2 and 3 were fed, in addition to the main diet, with probiotic preparation "Subtilis C" as part of the all-mash in a dosage of $3 \mathrm{~g} / \mathrm{kg}$ of allmash (rabbits of the $1^{\text {st }}$ experimental group) and $4 \mathrm{~g} / \mathrm{kg}$ of allmash (rabbits of the $2^{\text {nd }}$ experimental group).

To determine the meat efficiency, 3 heads of the rabbits from each group were slaughtered according to the method of all-Russian Institute of Animal husbandry, the meat quality was assessed according to standard procedures [22]. Studies were carried out using the material and technical base of the Institute of pathology, pharmacology and therapy (Voronezh).

\section{RESULTS AND DISCUSSION}

\section{A. Effect of probiotic preparation "Subtilis-C" on productivity and quality indices of pigs raw mea}

Feeding and meat qualities are considered to be main in the selection of technology elements for the production of pork on an industrial basis. Based on this, the aim of our research was to study the feed and meat qualities of pigs control and experimental groups.

The results of the study showed that the use of the probiotic "Subtilis" in the composition of complete all-mash SK-4-7 did not have a negative impact on the dynamics of live weight and average daily growth of the studied pigs (table 1).

During the study it was found that during the main period of scientific and economic experience, the absolute increase in live weight of young pigs of the control group was $79.70 \mathrm{~kg}$, those of experimental $-82.60 \mathrm{~kg}$, which is more than the animals of the control group, respectively, by $2.70 \mathrm{~kg}$. The level of growth intensity was also higher in young pigs of the experimental group: pigs for the period of experience exceeded the average daily gain of live weight of analogues from the control group by $6.5 \%$. At the same time, clinical parameters of animals during the experiment were within the physiological norm.

Indices that determine the intensity of pig breeding are feed consumption per unit of growth and precocity. For feed efficiency advantage was noted in experimental animals.

The results of the control slaughter showed that the slaughter live weight of the pigs of the experimental group in comparison with the animals of the control group was higher by $3.56 \mathrm{~kg}$, respectively (table 2). A similar pattern in experimental animals was revealed on the chilled carcass weight. As a result of researches it is established that the pigs of the experimental group received the studied preparation by the weight of the 
cooled carcass surpassed the animals of the control group by $4.13 \mathrm{~kg}$.

TABLE I. THE DYNAMICS OF LIVE WEIGHT AND VALUE OF THE GAINS OF THE EXPERIMENTAL ANIMALS ACCORDING TO THE BREEDING PERIODS $(\mathrm{N}=15)$

\begin{tabular}{|c|c|c|}
\hline \multirow{2}{*}{ Indices } & \multicolumn{2}{|c|}{ Group } \\
\hline & control & experienced \\
\hline \multicolumn{3}{|c|}{ Growing period } \\
\hline $\begin{array}{l}\text { Live weight, } \mathrm{kg} \text { : } \\
\text { at the beginning } \\
\text { at the end } \\
\text { Weight gain: } \\
\text { absolute, } \mathrm{kg} \\
\text { average daily, } \mathrm{g} \\
\% \text { of control group }\end{array}$ & $\begin{array}{c}30.00 \pm 0.05 \\
64.20 \pm 0.24 \\
34.20 \pm 0.14 \\
570.00+2.23 \\
100.00\end{array}$ & $\begin{array}{c}29.90 \pm 0.12 \\
66.51 \pm 0.18 \\
36.61 \pm 0.12 \\
601.00 \pm 6.00 \\
107.00\end{array}$ \\
\hline \multicolumn{3}{|c|}{ The fattening period } \\
\hline $\begin{array}{l}\text { Live weight, } \mathrm{kg} \text { : } \\
\text { at the beginning } \\
\text { at the end } \\
\text { Weight gain: } \\
\text { absolute, } \mathrm{kg} \\
\text { average daily, g } \\
\% \text { of control group }\end{array}$ & $\begin{array}{c}64.20 \pm 0.24 \\
109.70+0,38 \\
\\
45.50 \pm 0.34 \\
650.0 \pm 3.34 \\
100.00 \\
\end{array}$ & $\begin{array}{c}66.51 \pm 0.18 \\
112.50+0.24 \\
47.01 \pm 0.30 \\
672.0 \pm 7.14 \\
103.40 \\
\end{array}$ \\
\hline \multicolumn{3}{|c|}{ For the overall experiment } \\
\hline $\begin{array}{c}\text { Weight gain: } \\
\text { absolute, } \mathrm{kg} \\
\text { average daily, } \mathrm{g} \\
\% \text { of control group }\end{array}$ & $\begin{array}{c}79.70 \pm 0.44 \\
613.10 \pm+3.30 \\
100.00 \\
\end{array}$ & $\begin{array}{c}82.60 \pm 0.41 \\
653.10 \pm 5.00 \\
106.52 \\
\end{array}$ \\
\hline $\begin{array}{c}\text { Exchange energy costs, } \\
\text { ECU }\end{array}$ & 3.87 & 3.53 \\
\hline
\end{tabular}

TABLE II. SLAUGHTER AND MEAT QUALITIES OF EXPERIMENTAL $\operatorname{ANIMALS}(\mathrm{N}=3)$

\begin{tabular}{|l|c|c|}
\hline \multicolumn{1}{|c|}{ Indices } & control group & experimental group \\
\hline $\begin{array}{l}\text { Pre-slaughter live weight, } \\
\mathrm{kg}\end{array}$ & $109.70 \pm 0.42$ & $113.5 \pm 00.60$ \\
\hline Slaughter weight, $\mathrm{kg}$ & $75.02 \pm 0.57$ & $78.58 \pm 0.59$ \\
\hline Slaughter output, \% & $68.30 \pm 0.26$ & $69.23 \pm 0.18$ \\
\hline Chilled carcass weight, kg & $73.32 \pm 0.51$ & $77.45 \pm 0.56$ \\
\hline Weight of internal fat, kg & $1.70 \pm 0.06$ & $1.13 \pm 0.03$ \\
\hline $\begin{array}{l}\text { Backfat thickness at 6-7-th } \\
\text { thoracic vertebrae, mm }\end{array}$ & $25.07 \pm 0.19$ & $23.97 \pm 0.18$ \\
\hline $\begin{array}{l}\text { The area of the "muscle } \\
\text { eye", } \mathrm{cm}^{2}\end{array}$ & $30.80 \pm 0.24$ & $31.90 \pm 0.15$ \\
\hline
\end{tabular}

The area of the "muscle eye" in the gilts pigs of the experimental group in comparison with the analogues of the control group was higher by $3.57 \%$. The thickness of the fat was higher in young pigs of the control group. They outnumbered the gilts of the experimental group in this index respectively by $4.39 \%$. The data show the best expression of meat qualities in the pigs of the experimental group.

The quality of raw meat after processing should satisfy certain requirements. Post-slaughter evaluation of meat quality allows regulating the technological process and producing products of the planned quality.

The study of functional and technological properties showed the following: the $\mathrm{pH}$ of meat was in the range of 5.515.79. This index shows the normal process of maturation of meat and characterizes its high quality. Water-holding capacity was at a high enough level in the animals of the studied groups (55.2 - in the gilts of the control and 57.4 - of experimental groups). A lower value of WHC indicates a tendency to PSE defect. That is, the animals of the experimental group are, to some extent, more stress-resistant, and less prone to this defect, which is important for industrial technology.

\section{B. Effect of the probiotic preparation "Subtilis- $C$ " on the productivity and quality indicators of raw meat of rabbits}

In the Russian Federation rabbit breeding is a promising industry for the production of dietary meat. The meat of rabbits contains all the essential amino acids for humans, as well as it is fine-fibrous and has a high digestibility.

The nutritional value of meat depends largely on the content of muscle and fat tissue in the carcass. In this regard, the chemical composition of the flesh forms the nutritional and biological value of meat. The chemical composition of meat is characterized by inconstancy; therefore, it can change under the influence of various factors.

The quality of rabbit meat is influenced by factors such as the method of fattening, the method of breeding and the time of slaughter. The most important factor affecting the quality and chemical composition of meat is the diet of animals. In this regard, to obtain high-quality production rabbits need in balanced diet with all the necessary nutrients. Promising in this regard is the use of probiotics obtained by combining different strains that contribute to the transformation of nutrients in the diet to meat products $[27,28,30]$.

Our studies have shown that the use of the probiotic "Subtilis-C" in the diet of fattening rabbits led to an increase in the average daily growth and a decrease in feed conversion (table 3).

TABLE III. DYNAMICS OF LIVE WEIGHT OF RABBITS, G AND FEED CONVERSION, $\mathrm{KG}(\mathrm{X} \pm \mathrm{S})(\mathrm{N}=3)$

\begin{tabular}{|c|c|c|c|}
\hline \multirow{2}{*}{ Age, days } & \multicolumn{3}{|c|}{ Group } \\
\cline { 2 - 4 } & $\begin{array}{c}\text { Group 1 } \\
\text { (control) }\end{array}$ & $\begin{array}{c}\mathbf{2}^{\text {nd }} \text { group } \\
\text { (experimental 1) }\end{array}$ & $\begin{array}{c}\mathbf{3}^{\text {rd }} \text { group } \\
\text { (experimental 2) }\end{array}$ \\
\hline 1 & $40.18 \pm 0.11$ & $40.30 \pm 0.12$ & $40.48 \pm 0.13$ \\
\hline 60 & $1517.12 \pm 20.47$ & $1527.23 \pm 15.54$ & $1531.22 \pm 21.20$ \\
\hline 120 & $3200.5 \pm 20.17$ & $3338.5 \pm 20.14$ & $3525.2 \pm 16.00$ \\
\hline $\begin{array}{c}\text { Average } \\
\text { daily } \\
\text { increase }\end{array}$ & $28.55 \pm 0.75$ & $32.02 \pm 0.86$ & $34.23 \pm 0.74$ \\
\hline Safety, \% & 76.70 & 86.70 & 100.0 \\
\hline $\begin{array}{c}\text { Number of } \\
\text { heads }\end{array}$ & 46.0 & 52.0 & 60.0 \\
\hline $\begin{array}{c}\text { Feed } \\
\text { conversion, } \\
\text { kg }\end{array}$ & $4.50 \pm 0.17$ & $4.10 \pm 0.16$ & $3.84 \pm 0.21$ \\
\hline
\end{tabular}

Upon reaching the age of slaughter (120 days), rabbits of the 1 st group (control) were characterized by live weight, which was less than the mass of individuals of the 1st experimental group by $138.0 \mathrm{~g}$, or $4.31 \%(\mathrm{P}<0.05)$, the 2 nd experimental group - by $324.7 \mathrm{~g}$, or $10.15 \%(\mathrm{P}<0.01)$ (table 3$)$.

The conversion decreased in the 2 nd group by $8.88 \%$ and in the 3 rd - by $14.66 \%$ compared to the control. Moreover, the effect of the use of probiotics in young rabbits during the growing period was clearly dose-dependent. 
To determine the meat productivity of rabbits at the end of cultivation, we carried out the slaughter (table 4).

TABLE IV. SLAUGHTER QUALITIES AND MORPHOLOGICAL COMPOSITION OF RABBIT CARCASSES $(\mathrm{N}=3)$

\begin{tabular}{|l|c|c|c|}
\hline \multirow{2}{*}{ Age, days } & \multicolumn{3}{|c|}{ Group } \\
\cline { 2 - 4 } & Group 1 (control) & $\begin{array}{c}\mathbf{2}^{\text {nd }} \text { group } \\
\text { (experimental 1) }\end{array}$ & $\begin{array}{c}\mathbf{3}^{\text {rd }} \text { group } \\
\text { (experimental } \\
\text { 2) }\end{array}$ \\
\hline $\begin{array}{l}\text { Pre-slaughter } \\
\text { live weight, g }\end{array}$ & $3079.5 \pm 11.12$ & $3169.4 \pm 21.33$ & $3245.2 \pm 16.50$ \\
\hline $\begin{array}{l}\text { The mass of } \\
\text { steam carcass, } \\
\text { g }\end{array}$ & $1798.0 \pm 21.17$ & $1889.5 \pm 21.17$ & $2025.0 \pm 14.48$ \\
\hline $\begin{array}{l}\text { Relative \% to } \\
\text { control, \% }\end{array}$ & 100.0 & 105.0 & 115.9 \\
\hline $\begin{array}{l}\text { Lethal output, } \\
\%\end{array}$ & $58.38 \pm 0.15$ & $59.62 \pm 0.21$ & $62.39 \pm 0.17$ \\
\hline $\begin{array}{l}\text { Relative \% to } \\
\text { control, \% }\end{array}$ & 100.00 & 102.12 & 106.86 \\
\hline $\begin{array}{l}\text { Raw fat mass, } \\
\text { g }\end{array}$ & $110.0 \pm 1.56$ & $115.0 \pm 1.26$ & $120.0 \pm 1.22$ \\
\hline $\begin{array}{l}\text { Raw fat } \\
\text { output, \% }\end{array}$ & $6.11 \pm 0.54$ & $6.09 \pm 0.66$ & $5.94 \pm 0.58$ \\
\hline $\begin{array}{l}\text { The pulp } \\
\text { weight, g }\end{array}$ & $1293.0 \pm 12.10$ & $1386.0 \pm 13.44$ & $1548.0 \pm 15.32$ \\
\hline $\begin{array}{l}\text { Pulp output, } \\
\%\end{array}$ & $71.91 \pm 2.45$ & $73.35 \pm 2.49$ & $76.44 \pm 3.18$ \\
\hline Bone mass, g & $395.0 \pm 3.44$ & $388.5 \pm 3.78$ & $357.0 \pm 3.10$ \\
\hline $\begin{array}{l}\text { The } \\
\text { movement of } \\
\text { the bones, \% }\end{array}$ & $21.96 \pm 1.12$ & $20.56 \pm 1.15$ & $17.62 \pm 1.14$ \\
\hline Meat index & $3.27 \pm 0.78$ & $3.57 \pm 0.62$ & $4.33 \pm 0.55$ \\
\hline
\end{tabular}

As can be seen from table 4, the highest pre-slaughter weight of young rabbits was in the $2^{\text {nd }}$ experimental group (3245 g) and compared to the control - by $165.7 \mathrm{~g}$ more, or 5.38 $\%(\mathrm{P}<0.05)$. The carcass yield in the $2^{\text {nd }}$ experimental group was $62.33 \%$, which is more than in the control group and the $1^{\text {st }}$ experimental group - by 6.86 and $2.12 \%$, respectively.

The mass of muscle tissue in rabbits of the experimental groups was 7.12 and $24.22 \%(\mathrm{p}<0.01)$, respectively, more than in the rabbits of the control group.

TABLE V. CHEMICAL COMPOSITION OF RABBIT MEAT, $\mathrm{M} \pm \mathrm{S}$

\begin{tabular}{|l|c|c|c|}
\hline \multicolumn{1}{|c|}{ Indicator } & \multicolumn{3}{|c|}{ Group } \\
\cline { 2 - 4 } & $\begin{array}{c}\text { Group 1 } \\
\text { (control) }\end{array}$ & $\begin{array}{c}2^{\text {nd }} \text { group } \\
\text { (experienced } \\
\text { 1) }\end{array}$ & $\begin{array}{c}3^{\text {rd }} \text { group } \\
\text { (experienced } \\
\text { 2) }\end{array}$ \\
\hline $\begin{array}{l}\text { Mass fraction of } \\
\text { moisture, \% }\end{array}$ & $73.31 \pm 0.51$ & $72.84 \pm 0.62$ & $71.02 \pm 0.54$ \\
\hline $\begin{array}{l}\text { Mass fraction of } \\
\text { protein, \% }\end{array}$ & $19.40 \pm 0.22$ & $20.10 \pm 0.30$ & $22.00 \pm 0.34$ \\
\hline Mass fraction of fat, \% & $6.27 \pm 0.30$ & $6.01 \pm 0.21$ & $5.92 \pm 0.26$ \\
\hline Ash mass fraction, \% & $1.02 \pm 0.04$ & $1.05 \pm 0.02$ & $1.06 \pm 0.03$ \\
\hline Tryptophan, mg \% & $362.36 \pm 8.51$ & $366.39 \pm 8.51$ & $377.42 \pm 8.51$ \\
\hline Hydroxyproline, mg \% & $66.77 \pm 8.51$ & $64.78 \pm 8.51$ & $63.81 \pm 8.51$ \\
\hline $\begin{array}{l}\text { PQI (protein-quality } \\
\text { indicator) }\end{array}$ & $5.42 \pm 8.51$ & $5.65 \pm 8.51$ & $5.91 \pm 8.51$ \\
\hline
\end{tabular}

Table 5 shows the chemical composition of rabbit meat. The highest protein content, as well as amino acids tryptophan and hydroxyproline, was noted in the meat of rabbits of the $2 \mathrm{nd}$ experimental group, which seems to be associated with a higher transformation of nutrients under the action of feed probiotic additives "Subtilis $\mathrm{C}$ " in the protein component of muscle tissue.

According to the content of fat and ash, the rabbits of the experimental groups did not significantly differ from each other and the control group. From table 5 it follows that the content of tryptophan, the advantage was on the side of the rabbits of the experimental groups. The highest value of the proteinquality index was characterized by the meat of rabbits of group 3 , which indicates a greater value of meat.

The organoleptic evaluation of meat and broth of rabbits of control and experimental groups showed a positive effect of probiotic feed additive "Subtilis-C" on the formation of flavor profile of both boiled meat and broth. The highest score was characterized by samples of boiled meat and broth obtained from the carcasses of the $2^{\text {nd }}$ experimental group (8.7 and 8.3 points, respectively). Samples of boiled meat and broth obtained from the carcasses of rabbits of the control and the first group did not differ significantly (7.5 - 7.9 and $7.4-7.8$ points, respectively).

The veterinary and sanitary examination of meat and products of slaughter of rabbits of control and experimental groups did not reveal deviations from the existing norms (table $6)$.

Physical and chemical parameters of the meat corresponded to indices for fresh meat with normal course of autolytic processes and maturation.

TABLE VI. INDICATORS OF VETERINARY AND SANITARY EXAMINATION OF MEAT AND PRODUCTSOF SLAUGHTER OF RABBITS

\begin{tabular}{|c|c|c|c|}
\hline \multirow{2}{*}{ Indicator } & \multicolumn{3}{|c|}{ Group } \\
\cline { 2 - 4 } & $\begin{array}{c}\text { Group 1 } \\
\text { (control) }\end{array}$ & $\begin{array}{c}\text { Group 2 } \\
\text { (1 experimental } \\
\text { group) }\end{array}$ & $\begin{array}{c}\text { Group 3 } \\
\text { (2 experimental } \\
\text { group) }\end{array}$ \\
\hline \multicolumn{4}{|c|}{ Physical and chemical parameters } \\
\hline $\mathrm{pH}$ & $5.81 \pm 0.03$ & $5.84 \pm 0.04$ & $5.85 \pm 0.02$ \\
\hline $\begin{array}{c}\text { Reaction to } \\
\text { peroxidase }\end{array}$ & + & + & + \\
\hline $\begin{array}{c}\text { Reaction with } \\
\text { CuSO }\end{array}$ & - & - & - \\
\hline $\begin{array}{c}\text { Volatile fatty acids } \\
\text { Amino-ammonia } \\
\text { nitrogen }\end{array}$ & $2.10 \pm 0.03$ & $2.14 \pm 0.01$ & $2.16 \pm 0.01$ \\
\hline
\end{tabular}

\section{CONCLUSION}

Thus, the inclusion of the probiotic "Subtilis" for pigs in the groups of rearing and fattening, as well as feed stock of rabbits, in the complete compound feeds contributed to the improvement of productivity indicators, feed characteristics, and had a positive impact on the quality characteristics of raw meat.

It should be borne in mind that probiotics do not by themselves provide nutrients for additional products. But their biological potential helps to improve animal health, increase productivity, improve feed conversion. The use of the probiotic preparation "Subtilis-C" helped to reduce the cost of live weight gain of the experimental group of pigs, compared with the control. The level of profitability of pork production was higher by $3.6 \%$ in the experimental group compared to the control group. The rabbit production in the 1st and 2 nd experimental 
groups was higher by $1.8 \%$ and $2.6 \%$ respectively compared to the control group of rabbits. The use of the probiotic preparation "Subtilis-C" in the diet of young rabbits during the growing period has a positive effect on the growth rate and reduces feed costs.

Thus, the drug "Subtili-C" is a promising product of a number of probiotics used in animal feeding, which allows obtaining environmentally friendly products of pig and rabbit breeding while improving economic performance.

\section{References}

[1] A. N. Smirnova, "New times require new solutions," Meat industry, no. 8, pp. 53-59, 2016.

[2] G. V. Ovsyannikova, Y. A. Rakov, "The intensification of pork production through the use of specialized genotypes in the conditions of the Voronezh region," Technology and merchandising of agricultural products, no. 1 (8), pp. 21-25, 2017.

[3] A. C. Khudyakov, "The HACCP System - a guarantee of safety and quality in pork," Pig breeding, no. 3, pp. 13-15, 2016

[4] G. W. Tannok, "Normal microflora: an introduction to microbes inhabitating the human body," London: Chapman and Hall, 1995, p. 278.

[5] F. Cremonini, S. Di Caro, M. Covino et al, "Effect of different probiotic preparations on anti-Helicobacter pylori therapy-related side effects: a parallel group, triple blind, placebo-controlled study," Am. J. Gastroenterol, vol. 97, pp. 2744-2749, 2002.

[6] W. H. Close, "Production pigs without antibiotic growth promoters," Advancer in Pork production, Vol.11, pp.55-47, 2000.

[7] W. Clouse, J. A. Tailor-Pickard, A. Kocher, "Producing pigs without antibiotic growth promoters: Alternatives and Implications," Alltech. Inc, 2005 , p. 60

[8] D. Zigger, "Latest research in probiotics," AllAboutFeed, no. 5, pp. 1820, 2010.

[9] N. In. Abramkova, "Comparative effiency of spore-forming probiotics in the technology of growing pigs," Herald Krasgau, no. 8, pp. 173-176, 2015.

[10] S. V. Zlobin, "Probiotic subtilis in intensive pig breeding," Zootechnics, no. 11 , pp. 23-24, 2008.

[11] Russian Probotic Research Institite, "New products of Russian biotechnology from probiotics research Institute," retrieved from:www/Incubatory.EN/articles / newproducts. $\mathrm{Htm}$.

[12] A.V. Vostroilov, E. E. Kurchaeva, V. L. Pashchenko, E. V. Mikhailov, "The influence of probiotic VetKor on the meat productivity and morphological characteristics of the stomach and liver of rabbits," materials of XVII International scientific and research competition, Penza, pp. 29-34, 2018 [Contest The Best Scientific Article of 2018, 2018].

[13] A. V. Vostroilov, E. E. Kurchaeva, "The use of probiotic preparation "Vetom 3.0" in the diet of rabbits," In Proc. of IX International scientificpractical conference, pp. 156-159, 2017 [Breakthrough research: problems, patterns, prospects, 2017].

[14] H.H. Giang, T.Q. Viet, B. Ogle, J.E. Lindberg, "Growth performance, digestibility, gut environment and health status in weaned piglets fed a diet supplied with a complex of lactic acid bacteria alone or in combination with Bacillus subtilis and Saccharomyces boulardii," Living Sci, vol. 143, pp. 132-141, 2012

[15] A. M. Puchnin, A. A. Fomin, V. V. Smiryagin, "Probiotic supplements "Bacell" to feed in growing rabbits," Bulletin of Tambov University. Series: Natural and technical Sciences, vol. 17, no. 1, pp. 399-401, 2012.
[16] Chernenkov E. N., "Dynamics of changes in rabbit meat productivity at use in rations probiotic supplements "Biogumitel"," Herald of Orel state agrarian University, vol. 53, no. 2, pp. 62-67, 2015 .

[17] I. F. Gorlov, V. A. Barannikov, N. A. Yurina, N. A. Omelchenko, E. A. Maxim, "The productive effect of the complex probiotic supplements," Agricultural research magazine, no. 11, pp. 17-20, 2014.

[18] E. N. Chernenkov, I. V. Mironova, "The quality of rabbit meat when fed probiotic "Bogometer"," Bulletin of Altai state agrarian University, no. 10 (132), pp. 104-108, 2015.

[19] A.V. Vorobyov, "Veterinary and sanitary indicators of meat under the influence of experimental biological products," Russian journal of veterinary sanitation, hygiene and ecology, no. 1, pp. 210-215, 2012.

[20] E. N. Chernenkov, I. V. Mironova, A. J. Gizatov, "Influence of feeding of the drug Biohemical on carcass quality and morphological composition of carcasses of rabbits," Proceedings of the Orenburg state agrarian University, no. 4 (48), pp. 146-148, 2014.

[21] V. V. Avdienko, N. N. Zabashta, E. N. Golovko, "Rabbit Meat using extensive and moderately intensive cultivation technology," Collection of scientific works of the all-Russian research Institute of sheep and goat breeding, vol. 1, no. 9, pp. 9-11, 2016.

[22] L. V. Antipova, I. A. Glotova, I. A. Rogov, Research Methods of meat and meat products, Moscow: Kolos, 2001, p. 376.

[23] A.S. Klimenko, The effectiveness of the probiotic preparation "Subtilis" in the diet of rabbits," Rabbit breeding and animal husbandry, no. 2, pp. 6-7, 2009.

[24] P. Bielanski, J. Zajac, J. Fijal, "Effect of genetic variation of growth rate and meat quality in rabbits," In Proceedings of the 7th World Rabbit Congress, Valencia, Spain: World Rabbit Science Association, pp. 561$566,2000$.

[25] G. Capra, R. Martínez, F. Fradiletti, S. Cozzano, L. Repiso, R. Márquez et al, "Meat quality of rabbits reared with two different feeding strategies: with or without fresh alfalfa ad libitum," World Rabbit Science, vol. 21, no. 13 , pp. 23-32, 2013

[26] R.A. Iztelieva, L.K. Baibolova, S. Alberto, B.A. Rskeldiev, "Complex Research of Quality and Safety of Canned Food from Rabbit Meat," RJPBCS, vol. 8(1), pp 96-101, January - February 2017

[27] N.J. Sarbatova, V. J. Frolov, T. A. Ruleva, O. V. Sycheva, R. S. Omarov, "Complex assessment of meat efficiency and quality of meat rabbit breed "Chinchilla"," RJPBCS, vol. 8(1), pp. 1091-1095, January -February 2017.

[28] V. E. Ulitko, L. A. Pykhtina, O. A. Desyatov, J. V. Semenova, E. B. Savina, A. G. Aritkin, "Meat productivity and meat quality of broilers after the use of preprobiotic additives in their diets," RJPBCS, vol. 9(4), pp. 182-187, July-August 2018.

[29] S. Yu. Smolentsev, A. K. Volkov, E. K. Papunidi, G. R. Yusupova, N. V. Nikolaev, Y. V. Larina et al, "Meat productivity of cattle depending on the composition of the ration," RJPBCS, vol. 9(4), pp. 1247-1251, JulyAugust 2018.

[30] A. S. Mezhevikina, I. A. Lykasova, "Veterinary-sanitary characteristics of meat of chickens-broilers at application in a diet of a mixture of silicon," Successes of modern science and education, no. 4, vol. 1, pp. 2022, 2016.

[31] I. A. Korcheva, L. A. Orehova, "The use of probiotics in the manufacture of meat of chickens - broilers," Successes of modern science, no. 11, pp. 230-232, 2017.

[32] E. V. Korohova, V. V. Korobov, L. E. Markowskay, "Intelligent control system krolikovodcheskaya farm," Successes of modern science, vol. 11, no. 12 , pp. 38-44, 2016.

[33] E. V. Fudina "Development of agriculture and food security of Russia," Successes of modern science, no. 5, pp. 55-57, 2015.

[34] S. N. Belova, F. M. Rusakova, "The efficiency of enzyme preparation Roxazyme G2 in the diets of broiler chickens," Successes of modern science, vol. 10, no. 11, p. 124-127, 2016. 